23.「シベルクリン」劃分に関する研究

第 4 報「「ッ」劃分の䑤督学的性状について (九 細) 大友信也、江崎 苗

24. 発熱物質除去に関する研究

第臬報「イイン」交換福脂による血清 中の発熱物質除去に関する研究

（䈍 化）玉置 警、清崎俊之、大橋高明 (能 理) 永井英雄、山口俊雄

25.「トリパフラビン」殺菌腸「チフスワクチン」に

関寸る研究（第 2 報）（能 微）浮辺 正和

26. 赤疬菌「ロクチン」に関する研究

第 I 報 過沃素酸処理赤㾥菌体抗原の毒性

及び抗原性について

$$
\text { （熊 倾) 王置 馨、藤岡繁行 }
$$

27. 赤痢菌「ワクチン」に関する研究

第 II 報 過沃素酸処理菌体抗原の感染防禦

抗体生能について

$$
\begin{aligned}
& \text { (照 化) 王置 警、藤岡繁行 } \\
& \text { (留 微) 三并一久、三井清子 }
\end{aligned}
$$

28. S. paratyphi A の抗原桖造に関する研究

(中間報告) (屌大風土) 倉田 豊

29. Shigella Dysenteriae type $1 の 3$ 種の

阻止抗原の存在、並にその阻止機転について (艮大風土) 中源只郎

30. 恙虫病予跤「口クチン」に関する研究

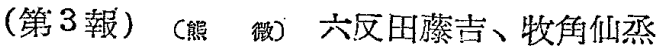

31. 日向熱（伝染性単核症）の病原体に関する研究

II 2、3の性状に就て

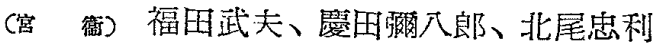

32. 日向熱（伝染性単核症）の病原体汇関する研究

III 中和試験及び補体結合反応依て

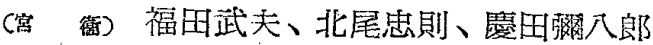

33. 伝染性単核症病原体に関寸る研究

第 1 報 病原体の大きさ湘定

(九 䋖) 大友信也 (九一内) 小林譔

34.「デング!熱「ウイルメ」の基本性質に関

する研究

(久) 細) 橋本勝之

35、狂犬病の予防及び治療法に関する研究

II 精製血清の中和試験、予防試験

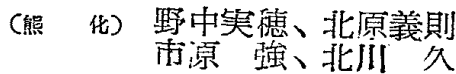

36. 畭缲狂犬病「ロクチン」に就て

铅 化) 北源義則、市源 強、市原鶴雄

\section{（特 别出演）}

細菌細胞膜と抗原抗体反応 (德 袺) 吉田長之

（特 別 講 演）

輓近に於ける腸内細菌研究の近歩、特に大腸菌の㾫 原性を中心として 北里磁所部曼 広㕕吉

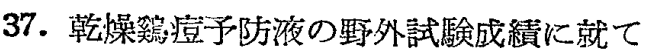

(熊 化) 小原速美、石田 弘、市原鶴雄

38. New Castle 病予防液の研究

第 I 報 二、三の Ađjuvant 添加 Vaccine について

留 化) 市原鶴雄、石田 弘、山田 昭

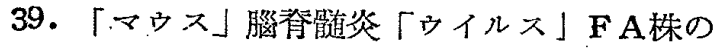

精製に関する研究（第工報）

(久) 細) 中村昌弘、児玉英治、中川 朔

40.「マゥス」脑脊髄炎「ウイルス」の赤血球

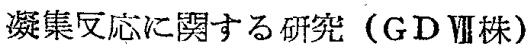

C久 細) 重藤已寿夫

41.「バクテリオフアージ」の宿主特異性に関する研究

II 赤痢菌生産「フアージ」に対する紫外線 と熱の不活化作用

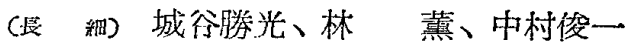

42.「バタテリオフアージ」宿主特異性に関する研究

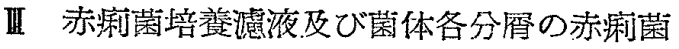
産生「ファージ」に站する態度

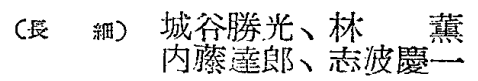

43. 不活性「ファージ」の吸着試験法について

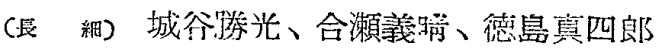

\section{九州雪科学会遠賀支部会講演要旨}

I 癌腫之肉腫との肉眼的金篮別 [大 曲]

一般腫瘍を肉腿的に鑑別する場合には、大体次の事 を参考とすべきです。

(1) 大きさ、

（2）形状 之は臓器内と表面とでは、自ら形が違う のは当然で、前者は限局性結節や湔賟性浸浿である事 が多く、後者では、結節状、乳跴状、分葉状、营状、

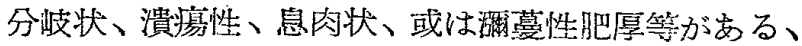
侣、一般に腫痔組織の即界は比較的判然としている事 が多いが、時火は不鮮明な事もある。

（3）硬度 之は硬軟種々です。癌や肉腫に於ても、 その種類丈は、その登生部位によつて違ふ。

（4）色腫瘍は一般に灰白色であるが、無諭、その 発生部位によつても色調は左右される。 melanoma 